\title{
ТЕРМІНИ ЯК АТРИБУТИ СОЦАЛЬНО-ПРАВОВИХ РАМОК ВИВЧЕННЯ ЗАМІННОГО ДОГЛЯДУ ЗА ДІТЬМИ В УМОВАХ РІЗНИХ СОЦІАЛЬНИХ СИСТЕМ
}

УДК:159.954.3: 316.614,5; 364.62-47-053.2

\author{
Бевз Г. М. \\ Доктор психологічних наук, дочент, \\ професор кафедри загальної та практичної психо- \\ логії ВДНЗ «Університет менеджменту освіти» \\ НАПН України, м. Київ (Україна)
}

\begin{abstract}
Анотація. Стаття присвячена порівняльному дослідженню системи замінного сімейного догляду за дітьми в Польщзі та Украӥни. В статті розкриваються психолінгвістичні, історичні та правові аспекти становлення назв замінних форм сімейного догляду за осиротілими дітьми. Аналізуючи особливості функціонування сімей замінного догляду за дітьми у Польщі та Украӥні автор ставить питання професійного підходу до перекладу правових термінів представнищтва законних прав та інтересів дитини в системі замінного сімейного догляду за дітьми та форм щзодо ї̈ реалізащії. Доведено, щчо назва форм замінного сімейного догляду за дітьми сприймається атрибутом загальної системи охорони дитинства, щуо вимагає при перекладі застосування принщипу кальки як при перекладі власних назв. Автор пропонує закріпити термін «замінна сім'я» як загальний, щчо вказує на виконання батьками замінного догляду за некревною дитиною.
\end{abstract}

Ключові слова: замінна сім'я, психологічних та правовий захист дітей, соціальні інститути, психолінгвістика, терміни, кроскультурні дослідження.

Постановка проблеми. Починаючи з 2002 року в Україні була започаткована прийомна сім'я як нова форма державного влаштування дітей. Цей процес був ініційований у 1991 році, коли розпочався рух перегляду засад утримання дітей в системі державної опіки після ратифікації Україною Конвенції ООН «Про права дитини» (1989). Наразі в Україні діють такі форми сімейного догляду за осиро- тілими дітьми як: прийомна та патронатна сім'я, дитячий будинок сімейного типу, а також традиційні для України форми: опіки та піклування і усиновлення. Традиція допомоги дитині засобом прийняття іï в свою родину не $\epsilon$ унікальною ні для України, ні для інших країн світу. Проте порівняльні наукові дослідження в даній сфері знань майже не виконуються вітчизняними дослідниками, а ще менше вони $€$ 
кроскультурними. Практика міжнародних обмінів в цій сфері знань також показала, що одним із суттєвих обмежень у ії вивченні виступає традиційна, нормативно закріплена в певній країні термінологія, яка позначає різні форми догляду за дітьми в ситуації їх зростання поза кревною сім'єю.

Аналіз останніх досліджень і публікацій. Наразі питанням ролі термінологічного апарату у вивченні психологічних аспектів догляду за дитиною у некревній для неї родині не приділяється належної уваги у працях науковців. Існуючі кроскультурні дослідження переважно виконані іноземними експертами і стосуються змістовного наповнення системи захисту дітей в ситуації їх осиротіння. Серед кроскультурних досліджень дана сфера знань представлена працею Річарда Картер (Великобританія), а також Шанті Джордж та Ніко ВанАвденговена (Нідерланди) [2; 11]. Зокрема питанням вивчення соціальної допомоги дітям та сім'ям в Польщі присвячені праці О. Романовської, О. Савчук, М. Огризко-Вієвіюровської [6; 7; 9]. Зафіксована нами відсутність системних порівняльних досліджень в сфері опіки над дітьми (та термінологічного апарату цієї сфери знань) вносить суттєві обмеження щодо обміну досвідом між спеціалістами країн з різних соціальним устроєм.

Тож метою даної статті с висвітлення ключових позицій проведення кроскультурних порівняльних досліджень в сфері опіки над дітьми та порівняння змістовного наповнення термінів щодо різних форм догляду за дітьми (на прикладі Польщі та України). Ocновними методами дослідження були: фокус групи учасників міжнародних семінарів по вивченню досвіду опіки над дітьми в різних країнах світу; порівняльний аналіз термінології щодо системи опіки над дітьми в Польщі та Україні, що здійснювався на основі вивчення першоджерел та аналізу нормативних документів.

Виклад основного матеріалу і результатів дослідження. Виходячи із різнобарв'я соціальних чинників ситуації проживання дитини в некревній (генетичнонеспорідненій) сім'ї ми скористувалися уніфікованим терміном замінна сім'я, що вказує на заміну (заміщення) дорослими батьківських функцій для дитини, яка була народжена не ними. Вираз «замінна турбота» та «замінні сім'я» вже ввійшли в практику наукових досліджень для позначення ситуацій зростання дітей в сім'ях, з якими вони не мають спорідненого походження (Й. Лангмеєєр, 3. Матейчек, В. Ослон, А. Холмогорова) [1; 4]. Таким чином до замінних сімей ми відносимо всі діючі форми в яких діти проживають і виховуються громадянами, які не виступають їхніми батьками за кровним спорідненням. В Україні це такі, як: опіка (піклування), прийомна та патронатна сім'я, а в Польщі «rodziny zastępcze» (заступницька сім’я) [1;9]. Такі поняття, як: замінне батьківство, функції 
замінного батьківства, замінна опіка, замінна сім'я будуть вказувати на різні аспекти функціонування сімей, в яких зростають та виховуються некревні діти, без уточнення рамок соціальної системи функціонування. Усиновлення теж можна розглядати формою замінної сім'ї, проте, на відміну від вищеназваних, усиновлена дитина набуває згідно судового рішення всі права генетично-спорідненої. Слід відмітити, що термін «замінна сім'я» зазнав чисельних трансформації, зокрема, у творах автора цієї статті можна зустріти такі його трактування, як «заміщувальна», «замісна» сім'я, що супроводжували різні етапи наукових пошуків і які були спростовані [1; 4]. Так термін «заміщувальна сім'я» є калькою російськомовного терміну «замещающая», а термін «замісна» - не достатньо розкриває суть поняття.

Також під час проведення дослідження ми звернули увагу на те, що юридичне трактування термінів, які стосуються опіки над дітьми, не завжди співпадають із їхнім побутовим розумінням. Даний факт спонукав нас до вивчення смислового наповнення юридичний термінів, які позначають різні форми сімейного догляду за некревними дітьми та особливостей їх трактування на побутовому рівні.

Дослідженням будо зафіксовано, що початок правових відносин між батьками та дитиною фіксує державна реєстрація акту народження дитини. Згідно даного акту батьки дитини виступають представниками іiі законних прав та інтересів, виконуючи їх до повноліття дитини, що фіксується оформленням паспорту - ознаки дієздатності та набуття статусу суб'єкта права [8; 10]. В повсякденному житті це означає, що батьки беруть на себе турботи по догляду за дитиною, а в процесі іiі підростання дбають про іiї виховання, привчаючи до соціального життя, праці та відповідальності перед людьми, постійно посилюючи їхню здатність до самостійності. В стародавні часи в Україні питання регулювання відносин між батьками та дітьми покладалося на звичаєве право, тобто здійснювалося відповідно до усталених традицій, які передавалися від покоління до покоління. Ціннісне ставлення до людини (в тому числі малого та похилого за віком) завжди супроводжувало життя українця: залишені без догляду діти чи ситуація старцювання батьків вважалося ганьбою для родини, а догляд за дітьми сприймався громадським обов'язком i не завжди співідносився із правовим актом. Підтримкою дітей в скрутні часи, слугував соціальний інститут кумівства, що забезпечував їм виживання та емоційний затишок на випадок смерті кревних батьків [1; 3; 4].

$$
\text { Нашим дослідженням були }
$$
встановлені сучасні чисельні факти здійснення догляду за покинутими дітьми людьми, які не вважали за необхідність зареєструвати надану допомогу дитині певним державним актом, оскільки свої дії 
більше вважали громадським обов'язком, ніж правочином. Дослідження показало, що питання юридичного оформлення дій догляду за некревними дітьми виступає дещо дивним для вітчизняного досвіду, а більшість людей навіть не надають значення відмінностям між різними формами допомоги осиротілій дитині. Такі форми влаштування дітей, як прийомна сім'я, опіка/піклування та усиновлення в більшості випадків не розрізняються населенням України. Щодо пересічних громадян Польщі, то вони показали більшу поінформованість про такі сім'ї, проте відмінності між різними їх типами теж виявилися недостатньо доступними для розуміння.

Можна сказати, що питання унікальності юридичних форм догляду за дітьми виступають значущими лише в конкретних життєвих випадках, а загалом дані теми не входять в актуальний перелік сфер інтересів населення і потребують постійного підкріплення соціальної політики. Досвід такого підкріплення у звичаєвому праві українця опирався на цінності грамади, які постійно посилювали та скріплювали соціальне життя людей, де найвищою оцінкою людини слугувало визнання громади, що укріплювалося такими подіями як одруження чи народження дитини [3; 4].

Спільним в Україні та Польщі є тенденція організації догляду за осиротілими дітьми в розширеній родині, що за Радянських часів в Україні юридично було закріплено як опіка/піклування; у Польщі - rodzina zastepcza (заступницька сім'я).

Інноваційний термін прийомна сім'я був введений в юридичну практику України в 1998 році Постановою Кабінету Міністрів від 2 березня 1998 року № 241 «Про проведення експерименту в Запорізькій області та затвердження Положення про прийомні сім'ю» та закріплений Законом України «Про охорону дитинства» (22.04.2001 р. № 2402-III). Змістовне навантаження поняття «прийомний прийомна» вказує на прийняття, приєднання когось або чогось, розширення меж власності, відповідальності та компетенції тощо. Даний термін одноразово означає додавання чогось до того, що вже $\epsilon$, і може нести ознаки як збільшення та збагачення (додавання того, що не вистачало, чи бажалось мати), так і зменшення і збіднення з причини наслідкового ущільнення чи обмеження. В Україні існувало явище «приймацтва», що вказувало на тих, хто приходив на набуте кимсь іншим житло, господарство тощо. Ставлення до приймаків завжди обумовлювалося причинами їхньої вікової та психологічної залежності а також економічної несамостійності. В ситуації нерівності чи приниження, приймаки не заохочувалися громадою і осуджувалися, оскільки їх стан свідчив про життєву нездатність та економічну несамостійність, залежність. Прикладом «приймацтва» може бути оселення хлопця після весілля в господарстві тестя, що могло 
здійснитися як за волею батька, так і за власним бажанням чи на запрошення. У випадку, коли приймак отримував рівні права в родині тестя i, автоматично, право голосу на сільських зборах, то громадськість не засуджувала такі шлюби, а навпаки допомагала, щоб нова сім'я могла набути незалежності як економічної, так і громадської. Приймаки поважалися громадою за умов їхнього поступового набуття самодостатності. В ситуації тривалої залежності приймаки соціально осуджувалися (позбавлялися права голосу в громаді) та розцінювалися тягарем громади 3 причини їхньої економічної неспроможності та несамостійності $[1 ; 3 ; 4]$.

Слід відмітити, що, набувши ознак правового терміну, поняття «прийомна сім'я», продовжує нести своє психолінгвістичне наповнення, що вказує на окреслені нами смислові поняття «додавання» та результуючого «обмеження», а також передбачає врахування історичного контексту. Наразі юридичний термін «прийомна сім'я» вказує на правовий статус сім’і, яка добровільно взяла на себе обов'язки турбуватися про дитину в ситуації функціональної неспроможності ії кревної родини [8]. Прийомна сім'я виступає формою державної опіки, оскільки утримання прийомної дитини в сім’ї здійснюється за рахунок державних коштів (не менше двох прожиткових мінімумів). В прийомну сім'ю може бути влаштовано від одного до чотирьох дітей. Метою прийомної сім’ї $є$ тимчасова підтримка дитини з наступним іiї поверненням до іiї кревної родини, термін якого обмежений лише повноліттям дитини. 3 цією метою вітаються дії по підтримці контактів дитини 3 їі кревною ріднею, створюючи тим самим підгрунтя для повернення дитини до родини за умов іiї реабілітації. Прийомним батькам гарантується виплата винагороди у розмір 30\% від встановленої суми утримання дитини.

На відміну від прийомної сім’ї в патронатній сім’ї передбачається виконання функцій догляду за дітьми на платній основі, а влаштування дітей здійснюється на короткотривалий термін (не більше одного року).

Термін «опіка та піклування» передбачає делегування дорослій особі певних функцій догляду за недієздатною особою - в даному випадку дитиною. Набуття дитиною ознак дієздатності $\epsilon$ поступовим процесом i співвідноситься із іiі віком. Згідно правових норм малолітня дитина до 14 років визнається недієздатною і над нею встановлюється опіка, а неповнолітня дитини старше 14 років - частково дієздатною і тому потребує піклування. Міри обмеження дієздатності малолітньої та неповнолітньої особи встановлено Цивільним Кодексом України (ст. 30-32). Стосовно дорослих, то опіка передбачає повну передачу дорослій особі функцій представництва прав та інтересів малолітньої дитини, а піклування часткове, стосовно дитини неповнолітнього віку. Розмежування функцій опіки та піклування регулюється законом [8; 10]. Слід відмі- 
тити, що встановлення опіки та піклування більше стосується ситуацій виховання дитини в сім’і родичів, одному з яких делегуються функції опікуна чи піклувальника. 32008 року в Україні утримання дитини під опікою/ піклуванням родичів передбачено державним бюджетом із квотами, встановленими згідно віку дітей (не менше двох прожиткових мінімумів). Функції опіки/піклування, які виконують родичі дитини, здійснюються на безоплатній основі.

Форма усиновлення передбачає прийняття в свою сім'ю дитини на правах сина чи доньки. Як правило люди прагнуть усиновити маленьку дитину, щоб вона відчувала себе народженою в цій родині і не мала сумнівів щодо свого походження. Дослідження зафіксувало прагнення усиновителів максимально наблизити дитину до свого генетичного коріння, усуваючи будь-які докази на користь іншого, засобом заміни ідентифікаційних даних дитини (прізвища, імені, дати народження, історію походження), місця попереднього проживання родини та роботи ï членів, вдаючись до імітації вагітності, створюючи легенди та міфи, уникаючи будь-якого прояснення соціальної ситуації кревної родини усиновленої дитини тощо. Такі дії створюють тайну в сім’ї, що негативно може позначитися на подальшій істоpiї родини та самій дитині [5]. Негативний вплив таємниць на психічний розвиток усиновленої дитини вже неодноразово доводився в численних наукових публікаціях $[1 ; 2 ; 5]$. На- разі питання відкритого усиновлення постають все більше актуальними, що робить дану форму турботи більш відкритою (тим самим i безпечнішою) для дитини, яка найбільше і потерпає від обмеженого доступу до інформації про своє походження [5].

Таким чином усиновлення, опіка/ піклування родичів, прийомна сім'я та патронатна сім'я $є$ різними формами турботи про дітей. Проте опитування показало, що всі вище перераховані форми замісної опіки пересічні громадяни в основному прирівнюють до усиновлення, розглядаючи прийняття дитини в свою родину або актом доброчинності, або бажанням бездітного подружжя мати дитину. Наразі виконання функції догляду за дитиною засобом іiї прийняття в свою родину не асоціюється ні із працею, ні із поняттям іiї оплати.

Тепер звернемося до юридичних термінів, які означають замісну опіку в Польщі [1; 2; 9; 13-16]. Щодо перекладу польського терміну «rodzina zastepcza», то слово «zastepowac» означає дію підміни, заміни одного іншим, або загородження доступу до чогось. На практиці юридичний термін «rodzina zastepcza», вказує на виконання батьківських функцій іншими особами і перекладається на українську мову як «заступницька сім'я», фіксуючи дві функції, а сему заміну та заступництво. В Польщі «заступницька сім'я» $є$ єдиною, не враховуючи усиновлення, нормативно закріпленою сімейною формою допомоги дитині. Проте в рамках системи соціальної допо- 
моги вона уточнюється різними типами згідно ступеня родинного зв'язку з дитиною, станом іiі здоров'я, кількості влаштованих дітей та фінансовою винагородою за працю. Таким чином у Польщі існує декілька типів заступницьких сімей, одні з яких мають родинний зв'язок із влаштованою дитиною «spokrewnione $z$ dzieckiem», тобто кровну спорідненість, інші не мають кровної спорідненості «niespokrewnione $z$ dzieckiem». Слово «кревний» найкраще вказує на генетичну (кровну) спорідненість між людьми. Саме тому ми його використали при перекладі аутентичного терміну «rodziny zastepcze spokrewnione z dzieckiem» - заступницькі кревні сім'ї [1].

Кожна дитина, влаштована в заступницьку сім'ю будь-якого типу отримує державну фінансову допомогу, яка частково покриває витрати родини на iї утримання та виховання. Заступницькі некревні сім’ї («rodziny zastepcze niespokrewnione z dzieckiem») додатково отримують винагородження у розмірі 10\% від встановленої квоти. Заступницькі некревні сім'ї, які пройшли спеціальну підготовку, отримують статус «zawodowe» (кадрова) і виконують свої функції на платній основі [12]. Переклад поняття «zawodowe» має два значення: професійний і кадровий, тобто такий, який має встановлений рівень підготовки і фіксує значущість особи, як підготовленої до певного виду праці. Поняття професійності включає такі смисли, як: кваліфікаційний рівень підго- товки, що базується на певному рівні освіти та передбачає певне місце праці і їі оплату. В Польщі не існує професії замінних батьків, проте оплата праці виконавцям замінної опіки над дітьми передбачена польським законодавством саме для заступницьких некревних сімей кадрового типу («rodziny zastepcze zawodowenie spokrewnione z dzieckiem»). Додаткова фінансова винагороду за працю встановлена заступницьким некревним сім'ям кадрового типу згідно їх виду: багатодітна («wielodzietne»), спеціального призначення («specjalistyczne») та сім'ї напоготові ( 'o’charakterze pogotowia rodzinnego»). Назва останнього типу сім’ї вказує на її готовність прийняти дитину на свою територію проживання в ситуації термінового вилучення дитини з іiї кревної родини по причині загрози для iï фізичного та психічного здоров'я. Заступницькі некревні сім'ї кадрового типу додатково отримують винагородження, що $є$ оплатою їхньої праці в розмірі до $120 \%$ встановленої квоти, але не більше ніж встановлений в Польщі мінімальний рівень заробітної плати. Ще раз хочемо відмітити, що найдоречнішим перекладом терміну «zawodowe» буде не професійна, а кадрова, тобто така, яка передбачає певний рівень підготовки та збереження кадрового складу підготовлених осіб, які продовжують на практичному рівні удосконалювати свої уміння у виконанні функцій замісної опіки над дітьми. Поєднання понять спеціальної підготовки та досвіду, що входить в поняття 
«кадри» визначає суть даного терміну.

Тип заступницької сім’ї кадрового типу спеціального призначення передбачає прийняття в сім'ю дітей, які мають ускладнення щодо здоров'я, поведінки тощо, що потребує від батьків спеціальних знань та цілодобового догляду.

Порівняльних аналіз форм сімейного влаштування дітей Польщі та України вказав, що при зовнішній подібності сімейної форми замінної опіки існують позиційні їх відмінності, що стосується: кількості влаштованих дітей; соціального статусу громадян - виконавців замінної опіки; наявності/відсутності оплати праці; наявності/відсутності державного забезпечення утримання дітей; терміну допустимого влаштування дітей, нормативного врегулювання питань щодо завдань по влаштуванню дітей та рівня правової відповідальності; норми взаємодії замінних батьків та органів влади; процедура влаштування та переведення дітей; завдань і форм здійснення нагляду та наявності/відсутності професійних агенцій підтримки тощо. Дослідження показало, що перераховані позиції відмінностей перш за все зумовлюються особливостями державного устрою кожної із країн, іiі політичною системою, традиціями та правовими засадами. Таблицею надаємо порівняльні характеристики замінної опіки над дітьми в Польщі та Україні (див. Табл. № 1).

Оскільки ми не мали на меті зробити детальний аналіз всіх аспектів системи замінної опіки над дітьми, то таблиця фіксує лише основні положення створення замінних сімей в різних соціально-економічних системах Польщі та України. Таблиця демонструє, що за кожним терміном виступає певний державний уклад та система соціального управління, актуальні діючі правові норми, що формують повноваження дорослих (приватних та уповноважених осіб) стосовно дітей та визначають конкретні наслідки при їх порушенні тощо. Дослідження засвідчило, що той чи інший термін може адекватно трактуватися лише в рамках діючої системи державного управління та соціального захисту тієї чи іншої країни. Застосування ж термінів системи охорони дитинства певної країни при перекладі термінів системи охорони дитинства іншої країни з іншим державним устроєм одноразово може привести до ототожнення і самих діючих систем, що не відповідає реальності. Дослідження показало недоречність при перекладі підміни термінологічного апарату системи опіки над дітьми однієї соціальної системи термінами, які діють в системі іншої країни (за принципом аналогії). Недотримання даного положення може призвести до хибного тлумачення базових понять замінного догляду за дітьми. Важливим аспектом щодо перекладу правових термінів системи опіки над дітьми виявився їхній історичний та психолінгвістичний аналіз, які фіксують напрямок розвитку громадської думки, що закріплюється в юридичних термінах, які в подальшому слугувати- 
Порівняння засад функціонування сімей замісної опіки в Польщі та Україні

Таблицяя № 1

\begin{tabular}{|c|c|c|c|}
\hline Категорії порівняння & Заступницька сім’я (Польща) & Прийомна сім’я (Україна) & Опіка/піклування (Україна) \\
\hline Покриття коштів & Місцевий бюджет & Загально державний бюджет & Загально державний бюджет \\
\hline Утримання дитини & $\begin{array}{l}\text { згідно встановленої квоти за } \\
\text { віком дитини (до } 7 \text { років та до } \\
\text { повноліття) та стану здоров'я }\end{array}$ & $\begin{array}{l}\text { згідно встановленої квоти за віком } \\
\text { дитини (до } 6 \text { років та до повноліт- } \\
\text { тя) } \\
\text { додаткове медичне фінансування } \\
\text { утримання дітей з ВІЛ та СНІД }\end{array}$ & $\begin{array}{l}\text { згідно встановленої квоти за віком } \\
\text { дитини (до } 6 \text { років та до повноліт- } \\
\text { тя) }\end{array}$ \\
\hline Винагорода за працю & $\begin{array}{l}\text { кревні - не передбачено } \\
\text { некревні (10\% квоти) } \\
\text { кадрові (120\% квоти, що відпо- } \\
\text { відає мінімальній зарплаті) }\end{array}$ & 30\% від оплати утримання дитини & не передбачено \\
\hline Підстава влаштування & $\begin{array}{l}\text { судове рішення } \\
\text { поліцейське вилучення із насту- } \\
\text { пним судовим рішенням }\end{array}$ & $\begin{array}{l}\text { адміністративне рішення виконав- } \\
\text { чого органу ради депутатів чи рай- } \\
\text { онної державної адміністрації }\end{array}$ & $\begin{array}{l}\text { адміністративне рішення виконав- } \\
\text { чого органу ради депутатів чи } \\
\text { районної державної адміністрації }\end{array}$ \\
\hline Житлові умови & житло замінних батьків & житло прийомних батьків & житло опікунів/піклувальників \\
\hline $\begin{array}{l}\text { Основа регулювання пра- } \\
\text { вовідносин під час функці- } \\
\text { онування }\end{array}$ & $\begin{array}{l}\text { двосторонній договір } \\
\text { (Повітовий Центр допомоги } \\
\text { сім'ям та замінні батьки) }\end{array}$ & $\begin{array}{l}\text { двосторонній договір (виконавчий } \\
\text { орган ради депутатів чи районна } \\
\text { державна адміністрація та прийом- } \\
\text { ні батьки) }\end{array}$ & $\begin{array}{l}\text { згідно заяви бажаючих взяти під } \\
\text { опіку/піклування дитину }\end{array}$ \\
\hline Надзір & $\begin{array}{l}\text { куратори районних сімейних } \\
\text { судів }\end{array}$ & служби у справах дітей (CСН) & служби у справах дітей (ССH) \\
\hline $\begin{array}{l}\text { Оцінка кандидатів на ство- } \\
\text { рення }\end{array}$ & $\begin{array}{l}\text { передбачена законодавством } \\
\text { два рівні оцінки для некревних } \\
\text { сімей та сімей кадрового типу, } \\
\text { що здійснюється на основі } \\
\text { добровільної згоди: } \\
\text { за формальними показниками } \\
\text { соціально-економічного поло- } \\
\text { ження } \\
\text { за показниками психолого- } \\
\text { педагогічної готовності }\end{array}$ & $\begin{array}{l}\text { передбачено законодавством лише } \\
\text { перший рівень оцінки за формаль- } \\
\text { ними показниками соціально- } \\
\text { економічного положення, що здійс- } \\
\text { нюється на основі добровільної } \\
\text { згоди }\end{array}$ & $\begin{array}{l}\text { передбачена законодавством на } \\
\text { рівні встановлення дієздатності } \\
\text { особи та наявності у неї житлової } \\
\text { площі для проживання дитини, що } \\
\text { здійснюється на основі добровіль- } \\
\text { ної згоди }\end{array}$ \\
\hline Кількість дітей & 1-3 (збільшення допускається) & 1-4 (збільшення не допускається) & не встановлено \\
\hline $\begin{array}{l}\text { Проходження попередньої } \\
\text { підготовки }\end{array}$ & $\begin{array}{l}\text { тільки для некревних сімей та } \\
\text { сімей кадрового типу за програ- } \\
\text { мою затвердженою Міністерст- } \\
\text { вом праці та соціальної політи- } \\
\text { ки }\end{array}$ & $\begin{array}{l}\text { всі без виключення за програмою } \\
\text { затвердженою Міністерством у } \\
\text { справах сім’ї, дітей та молоді }\end{array}$ & $\begin{array}{l}\text { з } 2008 \text { року передбачена підготов- } \\
\text { ка за програмою затвердженою } \\
\text { Міністерством у справах сім’ї, } \\
\text { дітей та молоді }\end{array}$ \\
\hline $\begin{array}{l}\text { Підвищення виховного } \\
\text { потенціалу }\end{array}$ & за потребою & один раз на два роки & не передбачено \\
\hline $\begin{array}{l}\text { Термін проживання дити- } \\
\text { ни }\end{array}$ & $\begin{array}{l}\text { необмежено до повноліття, } \\
\text { окрім: } \\
\text { сім'ї напоготові - до } 1 \text { року і } 3 \\
\text { місяці }\end{array}$ & $\begin{array}{l}\text { необмежено до повноліття з продо- } \\
\text { вженням до закінчення професійної } \\
\text { підготовки }\end{array}$ & необмежено до повноліття \\
\hline $\begin{array}{l}\text { Служби підготовки та } \\
\text { підтримки }\end{array}$ & $\begin{array}{l}\text { Пов’ятовий центр допомоги } \\
\text { сім'ям (РСРR) } \\
\text { територіальне відділення соціа- } \\
\text { льної допомоги (OPS) } \\
\text { недержавні агенції згідно ліцен- } \\
\text { зії }\end{array}$ & $\begin{array}{l}\text { Центри соціальних служб для сім’і, } \\
\text { дітей та молоді (ЦСССДМ) район- } \\
\text { ного та міського (обласного) рівня }\end{array}$ & $\begin{array}{l}\text { Центри соціальних служб для } \\
\text { сім'”̈, дітей та молоді (ЦСССДМ) } \\
\text { районного та міського (обласного) } \\
\text { рівня }\end{array}$ \\
\hline Форма звітності & $\begin{array}{l}\text { затверджена і проводиться } \\
\text { PCPR два рази на рік }\end{array}$ & довільна (1 раз на рік) & довільна (1 раз на рік) \\
\hline
\end{tabular}


муть регуляції соціальної політики країни. Тож уважне ставлення до термінології понять буде надавати можливість зафіксувати історію їх створення та змістовне наповнення, а також надихатиме шукати такі слова перекладу, що будуть передавати психолінгвістичну суть поняття та відображати автентичність його навантаження.

Слухачі міжнародних семінарів по обміну досвіду $з$ питань опіки над дітьми засвідчили, що переклад термінів даної сфери знань, здійснений за принципом аналогії, що не сприяє розумінню системи загалом і призводить до вихоплення лише окремих іiї аспектів. Дослідження показало, що перекладаючи юридичні терміни сфери представництва законних прав та інтересів системи опіки над дітьми країн різного соціального устрою, слід розцінювати їх як власні назви, при перекладі яких застосовується принцип «кальки».

Проведене дослідження надало можливість дійти важливого висновку, що основою для проведення порівняльних досліджень в сфері опіки над дітьми виступають знання щодо норм права, системи державного управління та системи соціального захисту в означеній сфері. Лише з опорою на вказані компетенції можливе здійснення кваліфікованого аналізу як системи реалізації прав дитини в країні іншого державного устрою так і психологічні аспекти життєдіяльності замінної сім’і. Здійснення фокусу уваги на людському досвіді догляду за дітьми без врахування ви- щенаведених чинників зумовить низку непорозумінь та помилок у сприймані інформації.

Переклад юридичних термінів сфери представництва прав та інтересів дітей державної опіки країни певного державного устрою має здійснюватися як переклад власних назв (за принципом кальки), що надасть можливість зберегти автентичність термінів різних соціальних систем і не допустить їх ототожнення при когнітивній оцінці. Дотримання даного принципу перекладу в ситуаціях обміну досвідом буде упереджувати помилки при співвіднесенні правових термінів та устрою державної системи опіки над дітьми певної країни, що складають єдине ціле системи охорони дитинства за певних умов державного устрою. Принцип перекладу, що опирається на пошук аналогу терміну, який використовується в одній соціальній системі для тлумачення терміну, що діє в іншій соціальній системі, виявився не допустимим для перекладу юридичних термінів системи опіки над дітьми.

Для позначення ситуацій надання турботи дитини в некревній родині загалом (без співвіднесення із системою державного устрою окремої країни) доречно застосовувати уніфікований термін - «замінна»: замінна опіка/сім’я, замінні батьки. Професійне ставлення до перекладу термінів системи замінної опіки над дітьми виступає ключовим моментом розуміння як системи загалом, так і їі acпектів. 
Зроблений аналіз соціально-правових рамок вивчення системи замінного догляду над дітьми в сім’ї може слугувати проведенню порівняльних кроскультурних досліджень в цій сфері і залишаються актуальними задля обміну досвідом спеціалістів країн з різним політичним, економічним та соціальним устроєм. Здійснення аналогічного порівняльного аналізу в інших країнах може слугувати перспективою для подальших досліджень.

\section{Перелік використаних джерел:}

1. Бевз Г. Прийомна сім'я: соціально-психологічні виміри : монографія / Г. Бевз. - К. : Слово, 2010. - 352 с.

2. Картер Річард. Опіка над діьми: сім'я і держава. Вивчення інституційної та сімейної форм опіки над дітьми у Центральній і Східній Європі й у країнах колишнього Радянського Союзу. / Річард Картер [Переклад з англійської] К.: Вид «Логос», 2005. - 88 с.

3. Культура і побут населення України: Навч. посібник / В. І. Наумко, Л. Ф. Артюх, В. Ф. Горленко та ін. К.: Либідь, 1993. - 288 с.

4. Лозко Г. С. Українське народознавст во./ Г. С. Лозко. К.: Зодіак-ЕКО, 1995. - 368 с.

5. Мельничук T. I. Соціально-психологічні чинники забезпечення ефективності процесу усиновлення дітей. дис.. канд.. психол. наук: 19.00.05 - соціальна психологія; психологія соціальної роботи. - К. : Інституту психології ім. Г. С. Костюка НАПН України. - К. : 2015 $276 \mathrm{c}$.

6. Огризко-Вісвіюровська М. Впровадж ення європейських стандартів у сферу надання соціальних послуг у Польщі / Соціальна політика і соціальна робота № 2 (37) 2007 C. $107-122$.

7. Романовська О. Фост ерна сім'я Великої Британії як соціально-педагогічне середовище підтримки особис- тості дитини: автореф. дис. на здобуття наук. ступ. канд. пед. наук : 13.00.05 «Соціальна педагогіка» / Національний педагогічний ун-т ім. М. П. Драгоманова. - К. : Нац. пед. ун-т ім. М. П. Драгоманова. — 2002. $20 \mathrm{c}$.

8. Ромовська 3. В. Сімейний кодекс України: науковопрактичний коментар. - К.: Видавничий Дім «Ін Юре», 2003. - 532 c.

9. Савчук $O$. Сист ема соціального захист у в Польщі: рефлексія візиту/О. Савчук // Соціальна політика і соціальна робота № 1 (36) 2007 С. 93 - 99

10. Сімейний кодекс України - Харків: Консум, 2002. $92 \mathrm{c}$.

11. Шанті Дж. У Учасники Фост ерного процесу: міжнародне порівняльне дослідження / Дж. Шанті, Н. Авденговен ; Фонд «Мистецтво, культура та наука». — Миколаїв, 2005. - 127 с.

12. Шутиенберггер А. А. Синдром предков. Трансгенерационные связи, семейные тайны, синдром годовщины, передача травм ипрактическое использованиегеносоциограммы. / Анн Анселин Шутценберггер. М.: Издво. Института Психотерапии, 2001. - 240 с.

13. Galewska G. Oprofesionalizacji rodyiców zastępczych. // Problemy opekunczo wychowawcye. Instytut Rozwoju Służb Społecynych. Listopad, № 9/2006 (454). P. 19-24.

14. Małe dziecko w systemie opieki społecznej i edukacji. / pod redakcją Marty Zahorskiej Małgorzaty Żytko. Warszawa. - 2004. 139 p.

15. Rodziny zastępcze. Problematuka prawna. / pod redakcji Marka Andrzejewskego. PW Formator. - Toruń, 2006. 332 p.

16. Winogrodzka L. Rodziny zastępcye i ich dyieci. Lublin.Wudawnictwo Uniwersytetu Marii CurieSkłodowskiej. - 2007. 232 p.

\section{References (Transliteration):}

1. Bevz H. Pryiomnasimia: sotsialno-psykholohichni vymiry : monohrafiia. - K.: Slovo, 2010. - 352 s. 
2. Karter Richard. Opika nad ditmy: simiai derzhava. Vyvchennia instytutsiinoi ta simeinoi form opiky nad ditmyu Tsentralniii Skhidnii Yevropiyu krainakh kolyshnoho Radianskoho Soiuzu. / Richard Karter [Pereklad zanhliiskoi] K.: Vyd «Lohos», 2005. - 88 p.

3. Kultura i pobut naselennia Ukrainy: Navch. posibnyk / V. I. Naumko, L. F. Artiukh, V. F. Horlenko ta in. K.: Lybid, 1993. - $288 \mathrm{p}$.

4. Lozko H. S. Ukrainske narodoznavstvo. - K. : ZodiakEKO, 1995. - 368 p.

5. Melnychuk T. I. Sotsialno-psykholohichni chynnyky zabezpechennia efektyvnosti protsesu usynovlennia ditei. dys.... kand.. psykhol. nauk: 19.00.05 - sotsialna psykholohiia; psykholohiia sotsialnoi roboty. - K. : Instytutu psykholohii im. H. S. Kostiuka NAPN Ukrainy. K. : $2015-276 \mathrm{p}$.

6. Ohryzko-Viieviiurovska M. Vprovadzhennia yevropeiskykh standartiv u sferu nadannia sotsialnykh posluh u Polshchi. - Sotsialna polityka i sotsialna robota № 2 (37) 2007 pp. 107 - 122.

7. Romanovska O. Fosterna simia Velykoi Brytanii yaksotsialno-pedahohichne seredovyshche pidtrymky osobystosti dytyny: avtoref. dys. nazdobuttianauk. stup. kand. ped. nauk : 13.00.05 «Sotsialnapedahohika» / Natsionalny ipedahohichnyiun-t im. M. P. Drahomanova. — K. :Nats. ped. un-tim. M. P. Drahomanova. — 2002. $20 \mathrm{p}$.

8. Romovska Z. V. Simeinyi kodeks Ukrainy: naukovopraktychnyi komentar. - K.: Vydavnychyi Dim «In Yure», 2003. - 532 p.

9. Savchuk O. Systema sotsialnoho zakhystu v Polshchi: refleksiia vizytu/ Sotsialna polityka i sotsialna robota № 1 (36) 2007. - pp. $93-99$.

10. Simeinyi kodeks Ukrainy - Kharkiv: Konsum, 2002. $92 \mathrm{p}$.

11. Shanti Dzh. Uchasnyky Fosternoho protsesu: mizhnarodne porivnialne doslidzhennia / Dzh. Shanti, N. Avdenhoven ; Fond «Mystetstvo, kultura ta nauka». Mykolaiv, 2005. - 127 p.

12. Shuttsenberhher A. A. Transheneratsyonnue sviazy, semeinыe tainы, syndrom hodovshchynы, peredachatravm y praktycheskoe yspolzovanye henosotsyohrammы. M.:Yzd-vo. Ynstytuta Psykhoterapyy, 2001. - 240 p.

13. Galewska G. O profesionalizacji rodyiców zastępczych. // Problemy opekunczo wychowawcye. Instytut Rozwoju Służb Społecynych. Listopad, № 9/2006 (454). - P. 19-24.

14. Małe dziecko w systemie opieki społecznej i edukacji. / pod redakcją Marty Zahorskiej Małgorzaty Żytko. Warszawa. - 2004. - 139 p.

15. Rodziny zastępcze. Problematuka prawna. / pod redakcji Marka Andrzejewskego. PW Formator. - Toruń, 2006. - 332 p.

16. Winogrodzka L. Rodziny zastępcye i ich dyieci. Lublin.Wudawnictwo Uniwersytetu Marii CurieSkłodowskiej. -2007 . -232 p.

\section{Galina Bevz}

Doctor of Psychology, Associate Professor of General and Applied Psychology at University of Educational of The National Academy of Pedagogical Sciences of Ukraine, Kyiv (Ukraine)

\section{TERMS AS ATTRIBUTES OF THE SOCIAL-LEGAL FRAMEWORK FOR THE STUDY OF REPLACEMENT CARE FOR CHILDREN UNDER DIFFERENT SOCIAL SYSTEMS}

\section{ABSTRACT}

The article is devoted to comparative research of the system of replacement family care for children in Poland and Ukraine. In this article discusses the psycholinguistic, historical and legal aspects of the formation of names to replacement forms of family care for orphaned children. 
In particular, the subject of detailed analysis was the following terms: «foster family» (Ukraine) and «protective family» (Poland). The article is noted that the legal terms that represent the different forms of care for orphaned children, is a little known for the ordinary citizens or not always coincide with their everyday understanding. An established fact of unification of the terminology of existing forms replacement of the childcare as in the home and in the exchange of experience with the experts from different countries forms the basis for the false representation of the existing system of child protection in the family care replacement. Analyzing the peculiarities the functioning of families of replacement care for children in Poland and Ukraine, the author raises the question of the professional approach to the translation of legal terms of representation of legal rights and interests of children in the system of replacement of family childcare and forms for its implementation. The research showed the inappropriateness on the translation substitution of terminological apparatus of the child care system as a one social terms system which operates in the system of another country (on the analogy). Failure to comply with of this provision may lead to misinterpretation of basic concepts of replacement child care. It has been proved that the name forms of replacement family care for the children perceived as an attribute of the general system of the child protection, requiring the translation of the principle of tracing paper as the translation of proper names. The author suggests to fix the term
« Replacement family » as a general, that indicating the performance to the parent's replacement care of the unrelated child.

Keywords: Replacement family, psychological and legal protection of children, social institutions, psycholinguistics, terms, crosscultural research.

\section{Бевз Галина Михайловна}

Доктор психологических наук, доцент, профессор кафедры общей и практической психологии Университета менеджмента образования Национальной академии педагогических наук Украинь, г. Киев (Украина)

\section{ТЕРМИНЫ КАК АТРИБУТ}

СОЦИАЛЬНОПРАВОВЫХ РАМОК ИЗУЧЕНИЯ ЗАМЕЩАЮЩЕГО УХОДА ЗА ДЕТЬМИ В УСЛОВИЯХ РАЗЛИЧНЫХ СОЦИАЛЬНЫХ СИСТЕМ

Аннотация. Статья посвящена сравнительному исследованию системы замещающего семейного ухода за детьми в Польше и Украине. В статье раскрываются психолингвистические, исторические и правовые аспекты становления названий замещающих форм семейного ухода за осиротевшими детьми. Анализируя особенности функционирования семей замещающего ухода за детьми в Польше и Украине автор ставит вопрос профессионального подхода к переводу правовых терминов представительства законных прав и интересов ребенка в системе замещающего се- 
мейного ухода за детьми и форм по его реализации. Доказано, что название форм замещающего семейного ухода за детьми воспринимается атрибутом общей системы охраны детства, что требует при переводе применения принципа кальки как при переводе собственных имен. Автор предлагает закрепить термин «заместительная семья» как общий, что указывает на выполнение родителями замещающего ухода за некровным ребёнком.

Ключевые слова: замещающая семья, психологическая и правовая защита детей, социальные институты, психолингвистика, термины, кроскультурные исследования. 